\title{
Role of TRPM7 in Cancer: Potential as Molecular Biomarker and Therapeutic Target
}

\author{
Nelson S. Yee \\ Division of Hematology-Oncology, Department of Medicine, PennState Health Milton S. Hershey Medical \\ Center, Program of Experimental Therapeutics, PennState Cancer Institute, The Pennsylvania State University \\ College of Medicine, 500 University Drive, Hershey, PA 17033, USA; nyee@pennstatehealth.psu.edu; \\ Tel.: +1-717-531-0003
}

Academic Editor: Arpad Szallasi

Received: 2 January 2017; Accepted: 29 March 2017; Published: 5 April 2017

\begin{abstract}
The transient receptor potential melastatin-subfamily member 7 (TRPM7) is a ubiquitously expressed ion channel with intrinsic kinase activity. Molecular and electrophysiological analyses of the structure and activity of TRPM7 have revealed functional coupling of its channel and kinase activity. Studies have indicated the important roles of TRPM7 channel-kinase in fundamental cellular processes, physiological responses, and embryonic development. Accumulating evidence has shown that TRPM7 is aberrantly expressed and/or activated in human diseases including cancer. TRPM7 plays a variety of functional roles in cancer cells including survival, cell cycle progression, proliferation, growth, migration, invasion, and epithelial-mesenchymal transition (EMT). Data from a study using mouse xenograft of human cancer show that TRPM7 is required for tumor growth and metastasis. The aberrant expression of TRPM7 and its genetic mutations/polymorphisms have been identified in various types of carcinoma. Chemical modulators of TRPM7 channel produced inhibition of proliferation, growth, migration, invasion, invadosome formation, and markers of EMT in cancer cells. Taken together, these studies suggest the potential value of exploiting TRPM7 channel-kinase as a molecular biomarker and therapeutic target in human malignancies.
\end{abstract}

Keywords: transient receptor potential; TRP; TRPM7; ion channel; cancer; biomarker; therapeutic target

\section{Introduction}

Ion channels play oncogenic and tumor suppressive roles in the pathogenesis of malignant neoplasms, and they have been implicated in the various hallmarks of cancer [1]. The transient receptor potential (TRP) superfamily of protein function as channels that control passage of various ions across biological membranes [2]. Activation of TRP channels typically results in transmembrane flow of cations such as $\mathrm{Ca}^{2+}$ and $\mathrm{Mg}^{2+}$ and, consequently, modulation of the associated signaling pathways. By detecting changes in various physical and chemical stimuli, TRP channels act as cellular sensors and transducers and mediate a variety of physiological responses [3]. Of the eight sub-families in the vertebral TRP family, the melastatin-subfamily (TRPM) possesses unique structural motifs and share common architectural features [4]. Growing evidence has shown that the TRPM7 member plays crucial roles in cellular processes, embryonic development, and human diseases, particularly cancer [5-8]. Accumulating data suggest the potential value of TRPM7 as a molecular biomarker and therapeutic target in human malignancies $[5,8,9]$.

The biochemical and electrophysiological properties of TRPM7 have been determined by in vitro assays, and the functional roles of TRPM7 have been studied in cultured cells and model organisms. Under physiological conditions, TRPM7 is a divalent cation-selective channel, and it possesses protein serine/threonine kinase activity [10-12]. The TRPM7 channel-kinase is ubiquitously expressed [13]. 
Spanning over $134.34 \mathrm{~kb}$ on the long arm of chromosome 15, the human TRPM7 gene consists of 39 exons, and four transcripts of its nine splice variants encode protein. The full-length human TRPM7 transcript contains 7263 nucleotides, and the encoded protein is composed of 1865 amino acids (MW $210 \mathrm{kDa}$ ) [14]. The basic structural features of the TRPM7 protein are shown in Figure 1. As a regulator of ionic homeostasis, the TRPM7 channel preferentially permits the flow of $\mathrm{Mg}^{2+}$ and $\mathrm{Ca}^{2+}$, and the $\mathrm{Mg}^{2+}$ influx through the TRPM7 channel in certain cell types can lead to altered intracellular levels of $\mathrm{Ca}^{2+}[12,15,16]$. The physiologically essential divalent metal cations $\left(\mathrm{Zn}^{2+}, \mathrm{Mn}^{2+}\right.$, $\left.\mathrm{Co}^{2+}\right)$ as well as environmentally toxic metals $\left(\mathrm{Ni}^{2+}, \mathrm{Cd}^{2+}, \mathrm{Ba}^{2+}, \mathrm{Sr}^{2+}\right)$ are also permeable through the TRPM7 channel $[10,12,17]$. In addition, as a member of the atypical protein kinase family called alpha-kinases [18], TRPM7 can autophosphorylate its serine and threonine residues [19]. The roles of the channel and kinase activities in the physiological functions of TRPM7 depend on the cell types and the molecular context.

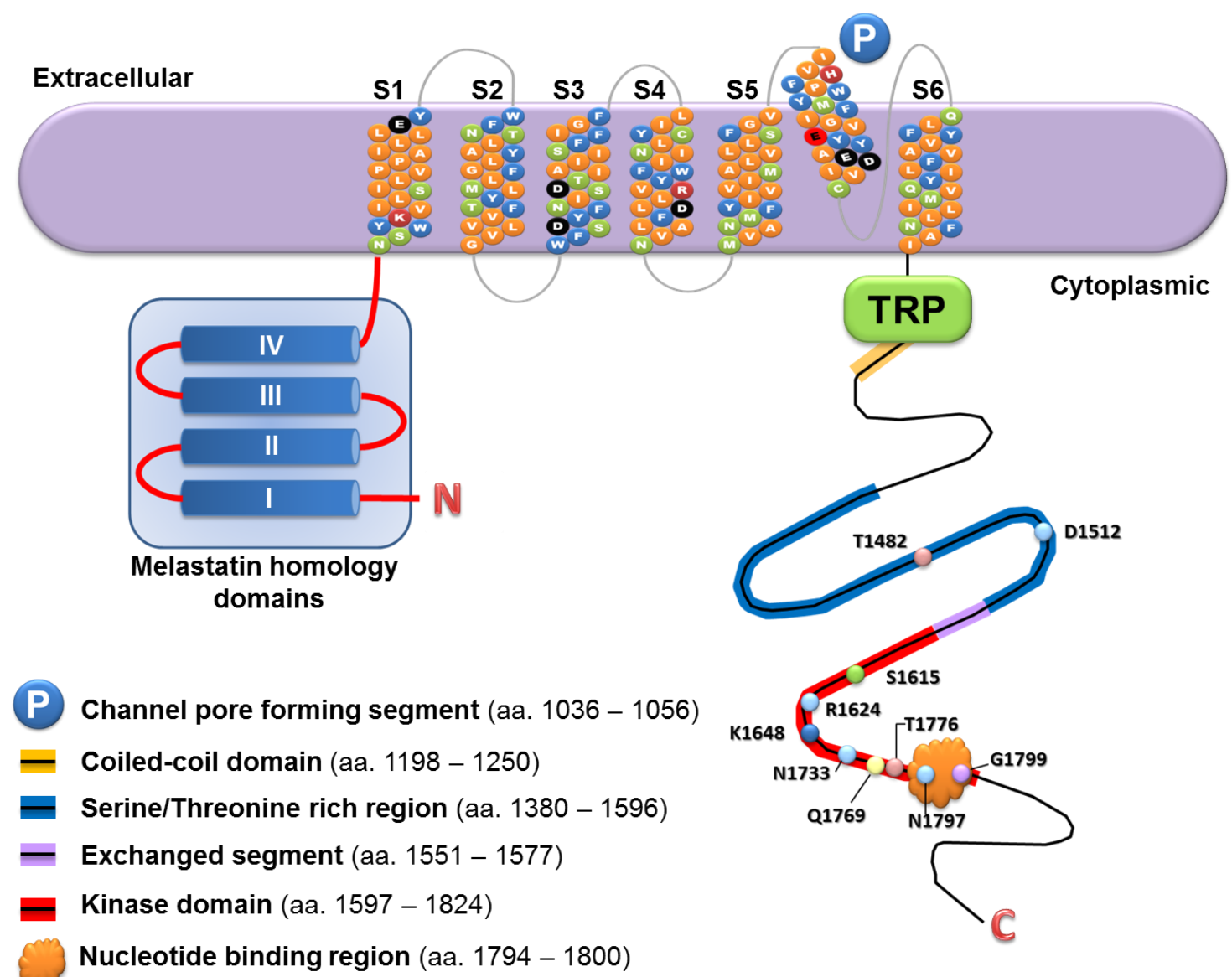

Figure 1. A schematic diagram to illustrate the protein structure of TRPM7 channel-kinase.

The TRPM7 protein contains six transmembrane segments (S1 to S6), each about 21 amino acid (aa.) residues in length. The amino $(\mathrm{N})$ and carboxyl $(\mathrm{C})$ terminal components embrace the transmembrane segments. The channel pore $(\mathrm{P})$ is shown slightly off plane and formed between S5 and S6. The two negatively charged amino acids (E1047 and E1052) in the pore forming loop are important for $\mathrm{Ca}^{2+}$ and $\mathrm{Mg}^{2+}$ permeability as well as $\mathrm{pH}$ sensitivity of the channel. Selected amino acid residues are shown and they play important roles in the functions of TRPM7 channel and kinase. The numbers of the amino acid residues correspond to human TRPM7 protein. This figure is adapted from Cells 2014, 3, 751-777 with permission from the publisher [5].

Experimental analyses of TRPM7 channel-kinase have revealed the molecular features that are important for its physiological responses and biological functions of TRPM7 in normal and cancerous 
cells. In vitro studies using site-directed mutagenesis in combination with electrophysiological and biochemical studies have generated insights into the molecular basis underlying the TRPM7 channel-kinase activities. Moreover, the amino acid residues of the TRPM7 protein that modulates its kinase activity, the sites of autophosphorylation and substrate binding, and their functional significance have been determined $[5,20]$. A growing body of data have supported diverse roles of TRPM7 in cellular proliferation, survival, differentiation, growth, and migration $[5,21,22]$. Studies using model organisms have revealed the crucial roles of TRPM7 in embryogenesis as well as the requirement of TRPM7 for development and functions of melanocytes, skeleton, thymus, nervous system, kidney, exocrine pancreas, urinary bladder, and megakaryocytes/platelets [5,23-26]. Accumulating evidence indicates that the TRPM7 channel-kinase plays oncogenic and tumor suppressing roles in various types of malignant tumors.

This purpose of this article is to discuss the emerging roles of the TRPM7 channel-kinase in various human malignancies, and the potential of exploiting TRPM7 as a cancer biomarker and therapeutic target. In this article, I will provide a review of the expression of TRPM7 in cancer, the roles of TRPM7 in cancer cells including proliferation, survival, migration, invasion, and epithelial-mesenchymal transition, as well as the role of TRPM7 in tumor growth and metastasis. The findings of TRPM7 genetic polymorphisms and mutations in various carcinoma will be presented. A list of chemicals that modulate TRPM7 expression and/or channel activity will be summarized. Finally, I will discuss the potential of developing TRPM7 channel-kinase as a molecular biomarker and therapeutic target for achieving the goal of precision oncology.

\section{Roles of TRPM7 in Human Cancer}

The TRPM7 channel-kinase has been implicated in a variety of human malignant tumors. In certain carcinoma examined, TRPM7 is aberrantly over-expressed in cell lines and/or tissues. Consistent with the functional roles of TRPM7 in the normal cell types and during organogenesis, numerous studies have shown that TRPM7 regulates cellular proliferation, survival, cell cycle progression, migration, and invasion in cancer cell lines. The signaling mechanisms underlying the biological functions of TRPM7 have been elucidated, and how aberrant expression and activity of TRPM7 contributes to neoplasia has begun to be understood. The expression and functional roles of TRPM7 in human malignant diseases are summarized in Table 1.

The functional roles of TRPM7 were examined by using RNA interference-mediated inhibition of TRPM7 expression or by using chemical inhibitors of TRPM7 channel activities as indicated. RNA interference is generally target-specific, though the extent of inhibition and the stability of the interfering agents are issues of potential concern. While the chemical inhibitors are relatively specific for TRPM7 activity, they may produce "off-target" effects depending on their concentrations being used. This table is adapted and modified from Cells 2014, 3, 751-777 with permission from the publisher [5]. 
Table 1. Expression and roles of TRPM7 channels in various human malignancies.

\begin{tabular}{|c|c|c|c|}
\hline Cancer & Expression & Functional roles of TRPM7 & References \\
\hline Pancreatic adenocarcinoma & $\begin{array}{l}\text { Increased in human pancreatic } \\
\text { adenocarcinoma tissues and cell lines. } \\
\text { Increased in chronic pancreatitis, pancreatic } \\
\text { intra-epithelial neoplasms }\end{array}$ & $\begin{array}{ll}\text { - } & \text { Required for cellular proliferation and cell cycle progression involving } \mathrm{Mg}^{2+} . \\
\text { - } & \text { Required for preventing replicative senescence. } \\
\text { - } & \text { Required for cell migration involving } \mathrm{Mg}^{2+} . \\
\text { Required for cell invasion. }\end{array}$ & {$[9,27-31]$} \\
\hline Breast carcinoma & $\begin{array}{l}\text { - Over-expression in human breast carcinoma } \\
\text { tissues and cell lines } \\
\text { Increased expression in infiltrating ductal } \\
\text { carcinoma with microcalcifications } \\
\text { - Somatic mutation T720S (Thr } \rightarrow \text { Ser) in a } \\
\text { breast infiltrating ductal carcinoma }\end{array}$ & $\begin{array}{ll}\text { - } & \text { Required for cancer cell proliferation in vitro. } \\
\text { - } & \text { Required for cancer cell migration in vitro and tumor metastasis in a mouse xenograft model. } \\
\text { - } & \text { Waixenicin A, TRPM7 blocker, inhibits growth and survival of breast cancer cells MCF-7. } \\
\text { - } & \text { TRPM7 involved in estrogen receptor-negative metastatic breast cancer cells migration through } \\
\text { kinase domain. } \\
\text { - } \quad \text { Involved in ginsenoside Rd-induced apoptosis in cells. } \\
\text { - Involved in epithelial mesenchymal transition. } \\
\text { TRPM7 mediates migration and invasion of breast cancer cells (MDA-MB-435) involving } \\
\text { phosphorylation of Src and MAPK. }\end{array}$ & {$[32-40]$} \\
\hline Gastric carcinoma & $\begin{array}{l}\text { - Expressed in human gastric adenocarcinoma } \\
\text { cell lines (AGS, MKN-1, MKN-45, } \\
\text { SNU-1, SNU-484) } \\
\text { - Somatic mutation M830V (Met } \rightarrow \text { Val) in } \\
\text { gastric adenocarcinoma }\end{array}$ & $\begin{array}{ll}\text { - } & \text { Required for cell survival involving } \mathrm{Mg}^{2+} \text {. } \\
\text { - } & \text { Waixenicin A, TRPM7 blocker, inhibits growth and survival of gastric cancer cells AGS. } \\
\text { - } & \text { Involved in ginsenoside Rd-induced apoptosis AGS cells. }\end{array}$ & {$[37,38,40-43$} \\
\hline Retinoblastoma & Existence in $5-8 \mathrm{~F}$ cells & $\begin{array}{ll}\text { - } & \text { Required for cell proliferation. } \\
\text { - } & \text { Required for } 5-8 \mathrm{~F} \text { cell migration. }\end{array}$ & [47] \\
\hline Melanoma & Expressed in cell lines & Not reported. & {$[48,49]$} \\
\hline Lung carcinoma & Expressed in A549 cells & Required for migration of A549 cells. & {$[50]$} \\
\hline Erythroleukemia & TRPM7-like currents in cell lines & Not reported. & [51] \\
\hline
\end{tabular}


Table 1. Cont.

\begin{tabular}{|c|c|c|c|}
\hline Cancer & Expression & Functional roles of TRPM7 & References \\
\hline Colon cancer & TRPM7 (Thr1482Ile) polymorphism & $\begin{array}{l}\text { TRPM7 (Thr1482Ile) polymorphism associated with elevated risk of both adenomatous and } \\
\text { hyperplastic polyps. } \\
\text { Individuals with TRPM7 (Thr1482Ile) polymorphism with a high Ca:Mg ratio intake in diet at a } \\
\text { relatively high risk of developing adenoma and hyperplastic polyps. }\end{array}$ & [52] \\
\hline Leukemia & Not reported & $\begin{array}{l}\text { - Waixenicin inhibits T cell leukemia (Jurkat T lymphocytes) and rat basophilic leukemia cells (RBL1) } \\
\text { through blocking TRPM7 channel activity. }\end{array}$ & [53] \\
\hline Neuroblastoma & Not reported & $\begin{array}{l}\text { - In mouse neuroblastoma cells (N1E-115), TRPM7 promotes formation of } \mathrm{Ca}^{2+} \text { sparking and } \\
\text { invadosome by affecting actomyosin contractility independent from } \mathrm{Ca}^{2+} \text { influx. } \\
\text { In vivo and in vitro studies using N1E-115 cells, TRPM7 promotes tumor metastasis in a mouse } \\
\text { xenograft model and cell migration in Boyden chamber. }\end{array}$ & {$[54,55]$} \\
\hline Ovarian carcinoma & $\begin{array}{l}\text { Somatic mutation } \mathrm{S} 406 \mathrm{C}(\mathrm{Ser} \rightarrow \mathrm{Cys}) \text { in } \\
\text { ovarian serous carcinoma }\end{array}$ & Not reported. & [40] \\
\hline Prostate cancer & $\begin{array}{l}\text { - Expressed in human prostate cancer cell } \\
\text { line DU145 }\end{array}$ & $\begin{array}{l}\text { Increased } \mathrm{Ca}^{2+} \text { to } \mathrm{Mg}^{2+} \text { ratio in prostate cancer cells enhances TRPM7-mediated currents and } \\
\text { promotes cellular entry of } \mathrm{Ca}^{2+} \text {, leading to increase in cell proliferation. }\end{array}$ & [56] \\
\hline Glioblastoma & $\begin{array}{l}\text { - Over-expressed in human glioblastoma cell } \\
\text { line U87 }\end{array}$ & $\begin{array}{l}\text { - Carvacrol inhibits TRPM7 and suppresses glioblastoma cell proliferation, migration, and invasion } \\
\text { - Xylokeletal B inhibits TRPM7 and suppresses glioblastoma cell proliferation and migration through } \\
\text { PI3K/Akt and MEK/ERK signaling } \\
\text { Midazolam inhibits TRPM7-mediated current and suppresess TRPM7 expression, and induces cell } \\
\text { cycle arrest and impairs proliferation }\end{array}$ & {$[57-59]$} \\
\hline
\end{tabular}




\subsection{Expression of TRPM7 in Cancer}

While it is ubiquitously expressed in normal tissues and cells, TRPM7 is aberrantly over-expressed in various types of malignant neoplasms (Table 1). Studies have demonstrated increased expression of TRPM7 in a panel of human pancreatic adenocarcinoma cells and tissues [9,27-31]. For each histological type of pancreatic tumors, the proportions of samples with corresponding TRPM7 expression levels have been reported [31]. The expression levels of TRPM7 in pancreatic adenocarcinoma tissues were found to positively correlate with the primary tumor size and tumor stages. These results suggest that aberrant over-expression of TRPM7 is associated with pancreatic tumor growth and metastasis. Besides pancreatic cancer, TRPM7 is aberrantly over-expressed in the cell lines and tissues of breast cancer [33] and glioblastoma [57]. Somatic mutations or polymorphisms of TRPM7 have been identified in breast carcinoma [40], gastric carcinoma [40], colon carcinoma [52], and ovarian carcinoma [40]. While the significance of those mutations and polymorphisms of TRPM7 remains to be determined, the Thr1482Ile polymorphism was shown to be associated with elevated dietary $\mathrm{Ca}^{2+}: \mathrm{Mg}^{2+}$ ratio and risk of colonic polyps [52].

\subsection{Roles of TRPM7 in Proliferation of Cancer}

The proliferative role of TRPM7 has been demonstrated in a variety of malignant tumors including pancreatic adenocarcinoma, breast carcinoma, head/neck carcinoma, retinoblastoma, and glioblastoma. In studies using human pancreatic adenocarcinoma cell lines, TRPM7 channels have been shown to be necessary for maintaining proliferation and preventing replicative senescence $[9,27,30]$. Additionally, downregulation of TRPM7 in human pancreatic cancer cells led to inhibition of proliferation by arresting the cells in the $\mathrm{G}_{0} / \mathrm{G}_{1}$ and $\mathrm{G}_{2} / \mathrm{M}$ phases of the cell cycle; these effects could be reversed by $\mathrm{Mg}^{2+}$ supplementation [9,27,30,31]. Moreover, small interfering RNA mediated silencing of TRPM7 induced senescence-associated $\beta$-galactosidase in pancreatic adenocarcinoma cells, suggesting a novel role of ion channels in replicative senescence of cancer [30]. Besides pancreatic cancer, TRPM7 is required for proliferation of cancer cells derived from a variety of malignant tumors. These include breast carcinoma [33], head/neck carcinoma [45], retinoblastoma [47], prostate carcinoma [56], T cell leukemia and rat basophilic leukemia [53], hypopharyngeal squamous cell carcinoma [46], and glioblastoma [57-59]. These results indicate that TRPM7 is required for proliferation of cancer cells and support a potential role of TRPM7 channels in tumor growth.

\subsection{Roles of TRPM7 in Survival of Cancer Cells}

A pro-survival role of TRPM7 channels has been demonstrated in various cancer cells, including pancreatic adenocarcinoma, gastric carcinoma, and breast carcinoma. In pancreatic cancer cells, small interfering RNA (siRNA)-induced knockdown of TRPM7 induced cell death without causing apoptosis [30]. In gastric cancer cells, TRPM7 is required for $\mathrm{Mg}^{2+}$-dependent cell survival, and involved in ginsenoside Rd-induced apoptosis [41-43]. In breast cancer cells, TRPM7 in involved in ginsenoside Rd-induced apoptosis [37]. Results of these studies suggest the mechanisms that mediate TRPM7-induced cell death may depend on the cell types; however, they support a role of TRPM7 in promoting survival of cancer cells and tumor growth.

\subsection{Roles of TRPM7 in Migration and Invasion of Cancer Cells}

Downregulation of TRPM7 in human cancer cells impaired cell migration and invasion; these effects could be reversed by $\mathrm{Mg}^{2+}$ supplementation. TRPM7 is required for cell migration in breast carcinoma that involves the kinase domain of TRPM7 as well as phosphorylation of Src and MAPK [32,34,36]. Similarly, TRPM7 is required for cell migration in nasopharyngeal carcinoma [44] and lung carcinoma [50]. In pancreatic adenocarcinoma, TRPM7 is required for $\mathrm{Mg}^{2+}$-dependent cell migration $[9,28]$ and cell invasion [31]. These results indicate that TRPM7-regulated $\mathrm{Mg}^{2+}$ homeostasis 
and the associated signaling are required for migration and invasion of cancer cells, and support a potential role of TRPM7 channels in tumor metastasis.

\subsection{Role of TRPM7 in Epithelial-Mesenchymal Transition}

Functional expression of TRPM7 plays a regulatory role in epithelial-mesenchymal transition (EMT), which represents a tumor microenvironment-induced invasive phenotype adopted by cancer cells in metastasis. Epidermal growth factor (EGF)- or hypoxia-induced EMT is associated with a transient elevation of intracellular $\mathrm{Ca}^{2+}$ and activation of signal transducer and activator of transcription 3 (STAT3). Silencing of TRPM7 in a breast cancer cell line (MDA-MB468) produced suppression of EGF-induced expression of vimentin and phosphorylation of STAT3, which are markers of EMT [39]. These data suggest that TRPM7 channel is involved in EMT and tumor metastasis.

\subsection{Roles of TRPM7 in Cancer Growth and Metastasis}

In vivo studies have provided insights into the roles of TRPM7 in tumorigenesis. Using a mouse xenograft model of human breast carcinoma, TRPM7 has been shown to be required for tumor metastasis [32]. This process involves TRPM7-mediated modification of focal adhesion number, cell-cell adhesion and polarized cell movement through regulation of myosin II-based cellular tension. These data are consistent with the in vitro evidence for the requirement of TRPM7 in cancer cell migration and invasion and supportive of a mechanosensory role of TRPM7 in tumor metastasis.

\subsection{Signaling Mechanisms for Functional Roles TRPM7 in Cancer}

The signaling pathways and the mechanisms that mediate the various cellular effects of TRPM7 in cancer cells have been elucidated. Depending on the cell types, the TRPM7 channel-kinase may interact and modulate the signaling pathways that mediate the effects of mitogens and inflammatory cytokines [22,27,50,58,60-67]. In a working model (Figure 2), the TRPM7 channel-kinase acts as a cellular sensor of the physical and chemical stimuli such as mechanical stretch, oxidative stress, changes in cell volume or osmolar gradient, and alterations in extracellular or cytosolic $\mathrm{pH}$. It also acts as a signal transducer by controlling ionic fluxes and modulating the mitogen- and cytokine-induced signaling pathways. Hypothetically, aberrantly expressed TRPM7 and dysregulated homeostasis of $\mathrm{Mg}^{2+}$ and $\mathrm{Ca}^{2+}$ in cancer cells modulate the epidermal growth factor (EGF)- or other mitogen-induced signaling pathways. These lead to perturbation of the signaling mediators and nuclear events, resulting in uncontrolled proliferation, survival, growth, and invasion of cancer cells.

The TRPM7 channel and kinase are constitutively active in resting cells. In response to physicochemical stimuli in the extracellular medium and in the cytosol, conduction of $\mathrm{Mg}^{2+}$ and $\mathrm{Ca}^{2+}$ through the TRPM7 channel can be positively or negatively regulated. The TRPM7 kinase can auto-phosphorylate itself and also phosphorylate various substrates in the cytocol. The resultant perturbation of ionic homeostasis and series of phosphorylation events produce activation or inhibition of the signaling molecules downstream of epidermal growth factor or other cytokines. Those signaling events induce transcription and translation of the cell cycle regulators, senescence-associated genes, and motility factors. These lead to a number of biological processes including cellular survival, proliferation, differentiation, growth, adhesion, rounding, migration, and invasion. Such cellular effects underlie TRPM7 channel-kinase mediated functions in physiological responses, embryonic development, and diseases such as cancer. This figure is adapted and modified from Cells 2014, 3, 751-777 with permission from the publisher [5]. 


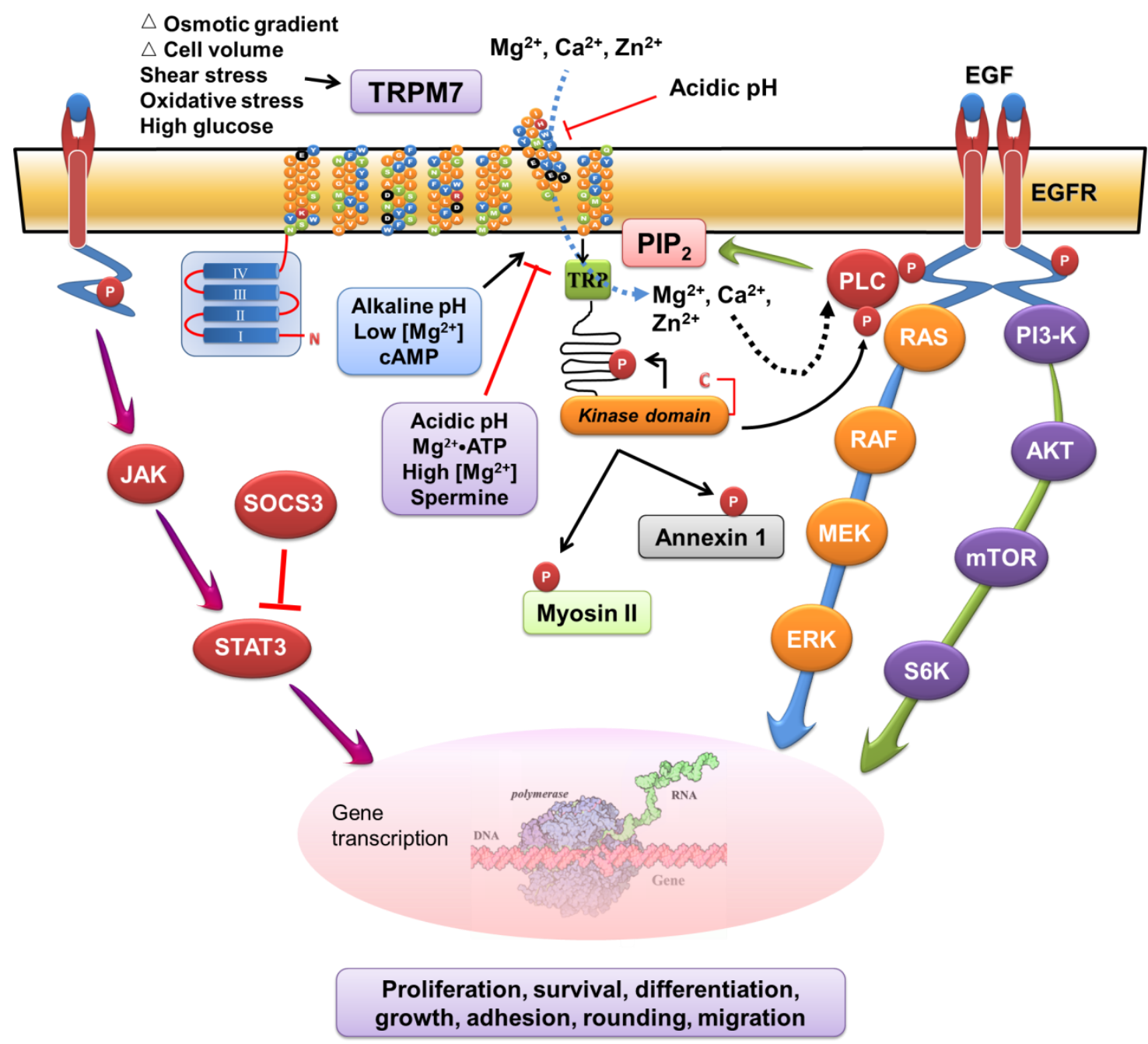

Figure 2. A working model of the signaling mechanisms that mediate the functional roles of TRPM7.

\section{TRPM7 Channel as Molecular Biomarker and Therapeutic Target in Cancer}

The findings of over-expression of TRPM7 protein and genetic mutations/polymorphisms in the TRPM7 gene in (pre)malignant diseases suggest the potential of exploiting it as a cancer biomarker. In pancreatic adenocarcinoma, a positive correlation was identified between the aberrant over-expression of TRPM7 and the tumor size/stages [31]. Results from the epidemiological study demonstrate that the TRPM7 variant T1482I, which was previously identified in patients with neurodegenerative diseases, is associated with dietary intake of $\mathrm{Ca}^{2+} / \mathrm{Mg}^{2+}$ and formation of the pre-malignant colonic adenoma/polyps [52]. Moreover, somatic mutations in TRPM7 have been identified in breast carcinoma (T720S, Thr->Ser), gastric carcinoma (M830V, Met->Val), and ovarian carcinoma (S406C, Ser->Cys) [40]. While the functional significance of these mutations remain to be determined, these data suggest the potential of exploiting TRPM7 as a molecular biomarker for prevention, early detection, and prognostication of cancer.

Furthermore, the aberrant expression and/or activity of TRPM7 in malignant tumors offer the opportunity of targeting TRPM7 for treatment of patients with cancer. A number of chemicals that modulate the expression and channel activity of TRPM7 have been identified and characterized [68]. These are not only valuable research tools to probe the mechanisms underlying the electrophysiological and cellular functions of TRPM7, but also potential therapeutic agents for various diseases, particularly cancer (Table 2). 
Table 2. Chemical modulators of TRPM7 channel activities as potential anti-cancer therapeutics.

\begin{tabular}{|c|c|c|c|c|}
\hline Chemicals & Effects on TRPM7 & Types of Cancer (Cell Lines) & Cellular Effects & References \\
\hline Midazolam & $\begin{array}{l}\text { Reduces expression of TRPM7, blocks TRPM7 } \\
\text { channel activity (TRPM7 currents) }\end{array}$ & $\begin{array}{l}\text { Human hypopharyngeal squamous cell } \\
\text { carcinoma (FaDu), human glioma } \\
\text { (MGR2) }\end{array}$ & Inhibits growth and proliferation with cell cycle arrest & {$[46,59]$} \\
\hline Ginsenoside Rg3 & Blocks TRPM7 channel activity (TRPM7 currents) & Human gastric adenocarcinoma (AGS) & $\begin{array}{l}\text { Inhibits growth and survival (MTT-based viability } \\
\text { assay: } \mathrm{IC}_{50} \text { of } 350 \mu \mathrm{M} \text { ) }\end{array}$ & [42] \\
\hline Ginsenoside Rd & Inhibits TRPM7 channel activity (TRPM7 currents) & $\begin{array}{l}\text { Human breast adenocarcinoma (MCF-7), } \\
\text { Human gastric adenocarcinoma (AGS) }\end{array}$ & $\begin{array}{l}\text { Inhibits proliferation and survival (MTT-based } \\
\text { viability assay: } \mathrm{IC}_{50} \text { of } 154 \mu \mathrm{M} \text { in MCF-7; } \mathrm{IC}_{50} \text { of } 131 \\
\mu \mathrm{M} \text { in AGS) }\end{array}$ & [37] \\
\hline Waixenicin A & $\begin{array}{l}\text { Inhibits TRPM7 channel activity (TRPM7 currents: } \\
\mathrm{IC}_{50} \text { of } 7 \mu \mathrm{M} \text { in } 0\left[\mathrm{Mg}^{2+}\right]_{\mathrm{i}} ; 16 \mathrm{nM} \text { in } 700 \mathrm{uM} \\
\left.\left[\mathrm{Mg}^{2+}\right]_{\mathrm{i}}\right)\end{array}$ & $\begin{array}{l}\text { T cell leukemia (Jurkat), } \\
\text { Rat basophilic leukemia (RBL1), } \\
\text { Human gastric adenocarcinoma (AGS), } \\
\text { Human breast adenocarcinoma (MCF-7), } \\
\text { Mouse neuroblastoma (N1E-115) }\end{array}$ & Inhibits proliferation, inhibits invadosome formation & {$[38,53,54]$} \\
\hline Carvacrol & Inhibits TRPM7 channel activity & Human glioblastoma (U87) & $\begin{array}{l}\text { Inhibits survival, migration, and invasion (MTT-based } \\
\text { viability assay: } \mathrm{IC}_{50} \text { of } 561 \mu \mathrm{M} \text { ) }\end{array}$ & [57] \\
\hline Xyloketal B & Inhibits TRPM7 channel activity (TRPM7 currents) & Human glioblastoma (U251) & $\begin{array}{l}\text { Inhibits survival, proliferation and migration } \\
\text { (MTT-based viability assay: } \mathrm{IC}_{50} \text { of } 287 \mu \mathrm{M} \text { ) }\end{array}$ & [58] \\
\hline NS8593 & $\begin{array}{l}\text { Inhibits TRPM7 channel activity (TRPM7 currents: } \\
\mathrm{IC}_{50} 1.6 \mu \mathrm{M} \text { in }\left[\mathrm{Mg}^{2+}\right]_{\mathrm{l}} \text {, IC } 50 \text { of } 5.9 \mathrm{uM} \text { in } 300 \mu \mathrm{M} \\
\left.\left[\mathrm{Mg}^{2+}\right]_{\mathrm{i}}\right)\end{array}$ & Human breast carcinoma (MDA-MB468) & $\begin{array}{l}\text { Inhibits epidermal growth factor-induced vimentin } \\
\text { expression (epithelial-mesenchymal transition) }\end{array}$ & {$[39,69]$} \\
\hline
\end{tabular}


Those chemical modulators can inhibit the TRPM7 channel activity and/or expression have been studied [37-39,42,46,53,54,57-59,69-76]. These inhibitors of TRPM7 channels include non-specific channel blockers, compounds derived from natural sources, and synthetic compounds. Most of their inhibitory actions are reversible at the concentrations tested and their $\mathrm{IC}_{50}$ values in the $\mu \mathrm{M}$ range. The chemical inhibitors of TRPM7 have been extensively used to study the mechanisms of the TRPM7 channel and kinase, and some of them show potential for therapeutic application.

On the other hand, a set of small molecule chemicals that activate the TRPM7 channel has been identified and characterized [77]. Among these TRPM7 agonists, the $\delta$-opioid receptor antagonist, naltriben, has been studied in detail. It was proposed that naltriben is a positive gating modulator of a TRPM7 channel, with a reversible stimulatory effect on the TRPM7 channel that is independent of $\left[\mathrm{Mg}^{2+}\right]_{\mathrm{ic}}$, and an $\mathrm{EC}_{50} 20.7 \mu \mathrm{M}$ [77]. In a recent report, two positive modulators of TRPM7, mibefradil and NNC 50-0396, have been recovered from a high throughout screen [78]. Mifebradil was shown to reversibly activate TRPM7-mediated $\mathrm{Ca}^{2+}$ entry and whole cell currents. In contrast to naltriben, mifebradil activates the TRPM7 channel only at physiological $\left[\mathrm{Mg}^{2+}\right]_{\text {ic }}$. These TRPM7 channel agonists will be useful tools to study the mechanistic actions of TRPM7, and their biological effects and potential medical applications remain to be determined.

Some of the TRPM7 modulators have been tested in cancer cells, such as a clinically used anesthetic (midazolam), naturally occurring compounds (ginsenoside Rg3, ginsenoside Rd, waixenicin A, carvacrol, and xyloketal B), and the synthetic compound NS8593. The chemically induced blockade of TRPM7 expression or its channel activity produces a variety of cellular effects including inhibition of cancer cell survival, proliferation, migration, invasion, and invadosome formation (Table 2). This suggests the potential value of developing these chemical modulators of TRPM7 into anti-cancer therapeutics.

\section{Conclusions}

TRPM7 is a ubiquitously expressed ion channel with intrinsic kinase activity that plays regulatory roles in a variety of cellular processes, physiological responses, early development, organogenesis, and human diseases, particularly cancer. Experimental evidence implicates important roles of the TRPM7 channel-kinase in the hallmarks of cancer, including uncontrolled cell cycle progression, survival, proliferation, growth, migration, invasion, epithelial-mesenchymal transition, and metastasis. While the functions mediated by TRPM7 in cancer appear to depend on the organ involved, the signaling mechanisms that mediate the functional roles of TRPM7 are related to the cellular and molecular context.

Future studies are indicated to understand how the TRPM7 channel-kinase sensing the physical and chemical changes inside the cells and in the microenvironment contributes to neoplasia. Animal models are urgently needed to determine the mechanistic roles of TRPM7 channel-kinase in the multistep process of carcinogenesis, such as tumor initiation, growth, invasion, and metastasis. The aberrant expression of TRPM7 and its genetic mutations/polymorphisms in malignant tumors suggest the opportunity for developing it as a clinical biomarker for prevention and early detection of cancer. Pharmacological inhibition of the TRPM7 channel in conjunction with genetic silencing of TRPM7 expression have not only provided mechanistic understanding of the biological functions of TRPM7, but also offer new hope for developing targeted therapeutics for achieving the goal of precision oncology.

Acknowledgments: The research work conducted in the author's Laboratory of Pancreatic Development and Cancer was supported by The Pennsylvania State University Physician Scientist Stimulus Package, the National Institute of Health (K08 DK 60529-05, R03 DK 071960-03, P30 NCI), the Pilot Grant in Translational Research from The University of Iowa Carver College of Medicine, the American Cancer Society Institutional Research Grant, and the Fraternal Order of Eagles Art Ehrmann Cancer Fund.

Conflicts of Interest: The author declares no conflict of interest. 


\section{References}

1. Yee, N.S. Ion channels. In Encyclopedia of Cancer, 3rd ed.; Springer: Berlin/Heidelberg, Germany, 2014; pp. 1-4.

2. Pedersen, S.F.; Owsianik, G.; Nilius, B. TRP channels: An overview. Cell Calcium 2005, 38, 233-252. [CrossRef] [PubMed]

3. Owsianik, G.; D’Hoedt, D.; Voets, T.; Nilius, B. Structure-function relationship of the TRP channel superfamily. Rev. Physiol. Biochem. Pharmacol. 2006, 156, 61-90. [PubMed]

4. Fleig, A.; Penner, R. The TRPM ion channel subfamily: Molecular, biophysical and functional features. Trends Pharmacol. Sci. 2004, 25, 633-639. [CrossRef] [PubMed]

5. Yee, N.S.; Kazi, A.A.; Yee, R.K. Cellular and developmental biology of TRPM7 channel-kinase: Implicated roles in cancer. Cells 2014, 3, 751-777. [CrossRef] [PubMed]

6. Fleig, A.; Chubanov, V. TRPM7. Mammalian Transient Receptor Potential (TRP) Cation Channels. In Handbook of Experimental Pharmacology; Nilius, B., Flockerzi, V., Eds.; Springer: Berlin/Heidelberg, Germany, 2014; p. 521.

7. Cabezas-Bratesco, D.; Brauchi, S.; Gonzales-Teuber, V.; Steinberg, X.; Valencia, I.; Colenso, C. The different roles of the channel-kinases TRPM6 and TRPM7. Curr. Med. Chem. 2015, 22, 2943-2953. [CrossRef] [PubMed]

8. Gautier, M.; Perriere, M.; Monet, M.; Vanlaeys, A.; Korichneva, I.; Dhennin-Duthille, I.; Ouadid-Ahidouch, H. Recent advances in oncogenic roles of the TRPM7 chanzyme. Curr. Med. Chem. 2016, 23, 4092-4107. [CrossRef] [PubMed]

9. Yee, N.S.; Chan, A.S.; Yee, J.D.; Yee, R.K. TRPM7 and TRPM8 ion channels in pancreatic adenocarcinoma: Potential roles as cancer biomarkers and targets. Scientifica 2012. [CrossRef] [PubMed]

10. Nadler, M.J.; Hermosura, M.C.; Inabe, K.; Perraud, A.L.; Zhu, Q.; Stokes, A.; Kurosaki, T.; Kinet, J.P.; Penner, R.; Scharenberg, A.M.; et al. LTRPC7 is a Mg.ATP-regulated divalent cation channel required for cell viability. Nature 2001, 411, 590-595. [CrossRef] [PubMed]

11. Runnels, L.W.; Yue, L.; Clapham, D.E. TRP-PLIK, a bifunctional protein with kinase and ion channel activities. Science 2001, 291, 1043-1047. [CrossRef] [PubMed]

12. Schmitz, C.; Perraud, A.L.; Johnson, C.O.; Inabe, K.; Smith, M.K.; Penner, R.; Kurosaki, T.; Fleig, A. Scharenberg, A.M. Regulation vertebrate cellular $\mathrm{Mg}^{2+}$ homeostasis by TRPM7. Cell 2003, 114, 191-200. [CrossRef]

13. Fonfria, E.; Murdock, P.R.; Cusdin, F.S.; Benham, C.D.; Kelsell, R.E.; McNulty, S. Tissue distribution profiles of the human TRPM cation channel family. J. Recept. Signal Transduct. Res. 2006, 26, 159-178. [CrossRef] [PubMed]

14. Kraft, R.; Harteneck, C. The mammalian melastatin-related transient receptor potential cation channels: An overview. Pflügers Arch. 2005, 451, 204-211. [CrossRef] [PubMed]

15. Aarts, M.; Iihara, K.; Wei, W.L.; Xiong, Z.G.; Arundine, M.; Cerwinski, W.; MacDonald, J.F.; Tymianski, M. A key role for TRPM7 channels in anoxic neuronal death. Cell 2003, 115, 863-877. [CrossRef]

16. Wei, C.; Wang, X.; Chen, M.; Ouyang, K.; Song, L.S.; Cheng, H. Calcium flickers steer cell migration. Nature 2009, 457, 901-905. [CrossRef] [PubMed]

17. Monteilh-Zoller, M.K.; Hermosura, M.C.; Nadler, M.J.; Scharenberg, A.M.; Penner, R.; Fleig, A. TRPM7 provides an ion channel mechanism for cellular entry of tract metal ions. J. Gen. Physiol. 2003, 121, 49-60. [CrossRef] [PubMed]

18. Fujiwara, Y.; Minor, D.L., Jr. X-ray crystal structure of a TRPM assembly domain reveals an antiparallel four-stranded coiled-coil. J. Mol. Biol. 2008, 383, 854-870. [CrossRef] [PubMed]

19. Matsushita, M.; Kozak, J.A.; Shimizu, Y.; McLachlin, D.T.; Yamaguchi, H.; Wei, F.Y.; Tomizawa, K.; Matsui, H.; Chait, B.T.; Cahalan, M.D.; et al. Channel function is dissociated from the intrinsic kinase activity and autophosphorylation of TRPM7/chak1. J. Biol. Chem. 2005, 280, 20793-20803. [CrossRef] [PubMed]

20. Kaitsuka, T.; Katagiri, C.; Beesetty, P.; Nakamura, K.; Hourani, S.; Tomizawa, K.; Kozak, J.A.; Matsushita, M. Inactivation of TRPM7 kinase activity does not impair its channel function in mice. Sci. Rep. 2014, 4, 5718. [CrossRef] [PubMed] 
21. Schilling, T.; Miralles, F.; Eder, C. TRPM7 regulates proliferation and polarization of macrophages. J. Cell Sci. 2014, 127, 4561-4566. [CrossRef] [PubMed]

22. Zeng, Z.; Leng, T.; Feng, X.; Sun, H.; Inoue, K.; Zhu, L.; Xiong, Z-G. Silencing TRPM7 in mouse cortical astrocytes impairs cell proliferation and migration via ERK and JNK signaling pathways. PLoS ONE 2015, 10, e0119912. [CrossRef] [PubMed]

23. Sah, R.; Mesirca, P.; Van den Boogert, M.; Rosen, J.; Mably, J.; Mangoni, M.E.; Clapham, D.E. Ion channel-kinase TRPM7 is required for maintaining cardiac automaticity. Proc. Natl. Acad. Sci. USA 2013, E3037-E3046. [CrossRef] [PubMed]

24. Ryazanova, L.V.; Hu, Z.; Suzuki, S.; Chubanov, V.; Fleig, A.; Ryazanov, A. Elucidating the role of the TRPM7 alpha-kinase: TRPM7 kinase inactivation leads to magnesium deprivation resistance phenotype in mice. Sci. Rep. 2014, 4, 7599. [CrossRef] [PubMed]

25. Watanabe, M.; Suzuki, Y.; Uchida, K.; Miyazaki, N.; Murata, K.; Matsumoto, S.; Kakizaki, H.; Tominaga, M. TRPM7 protein contributes to intercellular junction formation in mouse urothelium. J. Biol. Chem. 2015, 290, 29882-29892. [CrossRef] [PubMed]

26. Stritt, S.; Nurden, P.; Favier, R.; Favier, M.; Ferioli, S.; Gotru, S.K.; van Eeuwik, J.M.M.; Schulze, H.; Nurden, A.T.; Lambert, M.P.; et al. Defects in TRPM7 channel function deregulate thrombopoiesis and cytoskeletal architecture. Nat. Commun. 2016, 7, 11097. [CrossRef] [PubMed]

27. Yee, N.S.; Zhou, W.; Liang, I.-C. Transient receptor potential ion channel TRPM7 regulates exocrine pancreatic epithelial proliferation by $\mathrm{Mg}^{2+}$-sensitive Socs3a signaling in development and cancer. Dis. Mod. Mech. 2011, 4, 240-254. [CrossRef] [PubMed]

28. Rybarczyk, P.; Gautier, M.; Hague, F.; Dhennin-Duthille, I.; Chatelain, D.; Kerr-Conte, J.; Pattou, F; Regimbeau, J.M.; Sevestre, H.; Ouadid-Ahidouch, H. Transient receptor potential melastatin-related 7 channel is overexpressed in human pancreatic ductal adenocarcinomas and regulates human pancreatic cancer cell migration. Int. J. Cancer 2012, 131, E851-E861. [CrossRef] [PubMed]

29. Yee, N.S.; Yee, R.K. Ion channels as novel pancreatic cancer biomarkers and targets. In New Advances on Disease Biomarkers and Molecular Targets in Biomedicine; Lee, N.P.-Y., Ed.; Springer: New York, NY, USA, 2013.

30. Yee, N.S.; Zhou, W.; Lee, M.; Yee, R.K. Targeted silencing of TRPM7 ion channel induces replicative senescence and produces enhanced cytotoxicity with gemcitabine in pancreatic adenocarcinoma. Cancer Lett. 2012, 318, 99-105. [CrossRef] [PubMed]

31. Yee, N.S.; Kazi, A.A.; Li, Q.; Yang, Z.; Berg, A.; Yee, R.K. Aberrant over-expression of TRPM7 ion channels in pancreatic cancer: Required for cancer cell invasion and implicated in tumor growth and metastasis. Biol. Open 2015, 4, 507-514. [CrossRef] [PubMed]

32. Middelbeek, J.; Kuipers, A.J.; Henneman, L.; Visser, D.; Eidhof, I.; van Horssen, R.; Wieringa, B.; Canisius, S.V.; Zwart, W.; Wessels, L.F.; et al. TRPM7 is required for breast tumor cell metastasis. Cancer Res. 2012, 72, 4250-4261. [CrossRef] [PubMed]

33. Guilbert, A.; Gautier, M.; Dhennin-Duthille, I.; Haren, N.; Sevestre, H.; Ouadid-Ahidouch, H. Evidence that TRPM7 is required for breast cancer cell proliferation. Am. J. Physiol. Cell Physiol. 2009, 297, C493-C502. [CrossRef] [PubMed]

34. Guilbert, A.; Gautier, M.; Dhennin-Duthille, I.; Rybarczyk, P.; Sahni, J.; Sevestre, H.; Scharenberg, A.M.; Ouadid-Ahidouch, H. Transient receptor potential melastatin 7 is involved in oestrogen receptor-negative metastatic breast cancer cells migration through its kinase domain. Eur. J. Cancer 2013, 49, 3694-3707. [CrossRef] [PubMed]

35. Mandavilli, S.; Singh, B.B.; Sahmoun, A.E. Serum calcium levels, TRPM7, TRPC1, microcalcifications, and breast cancer using breast imaging reporting and data system scores. Breast Cancer 2012, 2013, 1-7.

36. Meng, X.; Cai, C.; Wu, J.; Cai, S.; Ye, C.; Chen, H.; Yang, Z.; Zeng, H.; Shen, Q.; Zou, F. TRPM7 mediates breast cancer cell migration and invasion through the MAPK pathway. Cancer Lett. 2013, 333, 96-102. [CrossRef] [PubMed]

37. Kim, B.J. Involvement of melastatin type transient receptor potential 7 channels in ginsenoside Rd-induced apoptosis in gastric and breast cancer cells. J. Ginseng Res. 2013, 37, 201-209. [CrossRef] [PubMed] 
38. Kim, B.J.; Nam, J.H.; Kwon, Y.K.; So, I.; Kim, S.J. The role of waixenicin A as transient receptor potential melastatin 7 blocker. Basic Clin. Pharmacol. Toxicol. 2013, 112, 83-89. [CrossRef] [PubMed]

39. Davis, F.M.; Azimi, I.; Faville, R.A.; Peters, A.A.; Jalink, K.; Putney, J.W., Jr.; Goodhill, G.J.; Thompson, E.W.; Roberts-Thomson, S.J.; monteith, G.R. Induction of epitheial-mesenchymal transition (EMT) in breast cancer cells is calcium signal dependent. Oncogene 2014, 33, 2307-2316. [CrossRef] [PubMed]

40. Greenman, C.; Stephens, P.; Smith, R.; Dalgliesh, G.L.; Hunter, C.; Bignell, G.; Davies, H.; Teague, J.; Butler, A.; Stevens, C.; et al. Patterns of somatic mutation in human cancer genomes. Nature 2007, 446, 153-158. [CrossRef] [PubMed]

41. Kim, B.J.; Kim, S.Y.; Lee, S.; Jeon, J.H.; Matsui, H.; Kwon, Y.K.; Kim, S.J.; So, I. The role of transient receptor potential channel blockers in human gastric cancer cell viability. Can. J. Physiol. Pharmacol. 2012, 990, 175-186. [CrossRef] [PubMed]

42. Kim, B.J.; Nah, S.Y.; Jeon, J.H.; So, I.; Kim, S.J. Transient receptor potential melastatin 7 channels are involved in ginsenoside Rg3-induced apoptosis in gastric cancer cells. Basic Clin. Pharmacol. Toxicol. 2011, 109, $233-239$. [CrossRef] [PubMed]

43. Kim, B.J.; Park, E.J.; Lee, J.H.; Jeon, J.H.; Kim, S.J.; So, I. Suppression of transient receptor potential melastatin 7 channel induces cell death in gastric cancer. Cancer Sci. 2008, 99, 2502-2509. [CrossRef] [PubMed]

44. Chen, J.P.; Luan, Y.; You, C.X.; Chen, X.H.; Luo, R.C.; Li, R. TRPM7 regulates the migration of human nasopharyngeal carcinoma cell by mediating $\mathrm{Ca}^{2+}$ influx. Cell Calcium 2010, 47, 425-432. [CrossRef] [PubMed]

45. Jiang, J.; Li, M.H.; Inoue, K.; Chu, X.P.; Seeds, J.; Xiong, Z.G. Transient receptor potential melastatin 7-like current in human head and neck carcinoma cells: Role in cell proliferation. Cancer Res. 2007, 67, 10929-10938. [CrossRef] [PubMed]

46. Dou, Y.; Li, Y.; Chen, J.; Wu, S.; Xiao, X.; Xie, S.; Tang, L.; Yan, M.; Wang, Y.; Lin, J.; et al. Inhibition of cancer cell proliferation by midazolam by targeting transient receptor potential melastatin 7. Oncol. Lett. 2013, 5, 1010-1016. [PubMed]

47. Hanano, T.; Hara, Y.; Shi, J.; Morita, H.; Umebayashi, C.; Mori, E.; Sumimoto, H.; Ito, Y.; Mori, Y.; Inoue, R. Involvement of TRPM7 in cell growth as a spontaneously activated $\mathrm{Ca}^{2+}$ entry pathway in human retinoblastoma cells. J. Pharmacol. Sci. 2004, 95, 403-419. [CrossRef] [PubMed]

48. McNeill, M.S.; Paulsen, J.; Bonde, G.; Burnight, E.; Hsu, M.Y.; Cornell, R.A. Cell death of melanophores in zebrafish trpm7 mutant embryos depends on melanin synthesis. J. Investig. Dermatol. 2007, 127, 2020-2030. [CrossRef] [PubMed]

49. Guo, H.; Carlson, J.A.; Slominski, A. Role of TRPM in melanocytes and melanoma. Exp. Dermatol. 2012, 21, 650-654. [CrossRef] [PubMed]

50. Gao, H.; Chen, X.; Du, X.; Guan, B.; Liu, Y.; Zhang, H. EGF enhances the migration of cancer cells by up-regulation of TRPM7. Cell Calcium 2011, 50, 559-568. [CrossRef] [PubMed]

51. Mason, M.J.; Schaffner, C.; Floto, R.A.; Teo, Q.A. Constitutive expression of a $\mathrm{Mg}^{2+}$-inhibited $\mathrm{K}^{+}$current and a TRPM7-like current in human erythroleukemia cells. Am. J. Physiol. Cell Physiol. 2012, 302, C853-C867. [CrossRef] [PubMed]

52. Dai, Q.; Shrubsole, M.J.; Ness, R.M.; Schlundt, D.; Cai, Q.; Smalley, W.E.; Li, M.; Shyr, Y.; Zheng, W. The relation of magnesium and calcium intakes and a genetic polymorphism in the magnesium transporter to colorectal neoplasia risk. Am. J. Clin. Nutr. 2007, 86, 743-751. [PubMed]

53. Zierler, S.; Yao, G.; Zhang, Z.; Kuo, W.C.; Porzgen, P.; Penner, R.; Horgen, F.D.; Fleig, A. Waixenicin A inhibits cell proliferation through magnesium-dependent block of transient receptor potential melastatin 7 (TRPM7) channels. J. Biol. Chem. 2011, 286, 39328-39335. [CrossRef] [PubMed]

54. Visser, D.; Langeslag, M.; Kedziora, K.M.; Klarenbeek, J.; Kamermans, A.; Horgen, F.D.; Fleig, A.; van Leeuwen, F.N.; Jalink, K. TRPM7 triggers $\mathrm{Ca}^{2+}$ sparks and invadosome formation in neuroblastoma cells. Cell Calcium 2013, 54, 404-415. [CrossRef] [PubMed]

55. Middlebeek, J.; Visser, D.; Henneman, L.; Kamermans, A.; Kuipers, A.J.; Hoogerbrugge, P.M.; Jalink, K.; van Leeuwen, F.N. TRPM7 maintains progenitor-like features of neuroblastoma cells: Implications for metastasis formation. Oncotarget 2015, 6, 8760-8776. [CrossRef] [PubMed]

56. Sun, Y.; Selvaraj, S.; Varma, A.; Derry, S.; Sahmoun, A.E.; Singh, B.B. Increase in serum $\mathrm{Ca}^{2+} / \mathrm{Mg}^{2+}$ ratio promotes proliferation of prostate cancer cells by activating TRPM7 channels. J. Biol. Chem. 2013, 288, 255-263. [CrossRef] [PubMed] 
57. Chen, W.L.; Barszczyk, A.; Turlova, E.; Deurloo, M.; Liu, B.; Yang, B.B.; Rutka, J.T.; Feng, Z.P.; Sun, H.S. Inhibition of TRPM7 by carvacrol suppresses glioblastoma cell proliferation, migration and invasion. Oncotarget 2015, 6, 16321-16340. [CrossRef] [PubMed]

58. Chen, W.L.; Turlova, E.; Sun, C.L.; Kim, J.S.; Huang, S.; Zhong, X.; Guan, Y.Y.; Wang, G.L.; Rutka, J.T.; Feng, Z.P.; et al. Xyloketal B suppresses glioblastoma cell proliferation and migration in vitro through inhibiting TRPM7-regulated PI3K/Akt and MEK/ERK signaling pathways. Mar. Drugs 2015, 13, 2505-2525. [CrossRef] [PubMed]

59. Chen, J.; Dou, Y.; Zheng, X.; Leng, T.; Lu, X.; Ouyang, Y.; Sun, H.; Xing, F.; Mai, J.; Gu, J.; et al. TRPM7 channel inhibition mediates midazolam-induced proliferation loss in human malignant glioma. Tumour Biol. 2016, 37, 14721-14731. [CrossRef] [PubMed]

60. Runnels, L.W.; Yue, L.; Clapham, D.E. The TRPM7 channel is inactivated by PIP 2 hydrolysis. Nat. Cell Biol. 2002, 4, 329-336. [CrossRef] [PubMed]

61. Dorovkov, M.V.; Ryazanov, A.G. Phosphorylation of annexin I by TRPM7 channel-kinase. J. Biol. Chem. 2004, 279, 50643-50646. [CrossRef] [PubMed]

62. Jin, J.; Desai, B.N.; Navarro, B.; Donovan, A.; Andrews, N.C.; Clapham, D.E. Deletion of Trpm7 disrupts embryonic development and thymopoiesis without altering $\mathrm{Mg}^{2+}$ homeostasis. Science 2008, 322, 756-760. [CrossRef] [PubMed]

63. Sahni, J.; Scharenberg, A.M. TRPM7 ion channels are required for sustained phosphoinositide 3-kinase signaling in lymphocytes. Cell Metab. 2008, 8, 84-93. [CrossRef] [PubMed]

64. Sahni, J.; Tamura, R.; Sweet, I.R.; Scharenberg, A.M. TRPM7 regulates quiescent/proliferative metabolic transitions in lymphocytes. Cell Cycle 2010, 9, 3565-3574. [CrossRef] [PubMed]

65. Clark, K.; Middlebeek, J.; Lasonder, E.; Dulyaninova, N.G.; Morrice, N.A.; Ryazanov, A.G.; Bresnick, A.R.; Figdor, C.G.; van Leeuwen, F.N. TRPM7 regulates myosin IIA filament stability and protein localization by heavy chain phosphorylation. J. Mol. Biol. 2008, 378, 790-803. [CrossRef] [PubMed]

66. Inoue, K.; Xiong, Z.-G. Silencing of TRPM7 promotes growth/proliferation and nitric oxide production of vascular endothelial cells via the ERK pathway. Cardiovasc. Res. 2009, 83, 547-557. [CrossRef] [PubMed]

67. Liu, M.; Inoue, K.; Leng, T.; Guo, S.; Xiong, Z.G. Trpm7 channels regulate glioma stem cell through stat3 and notch signaling pathways. Cell. Signal. 2014, 26, 2773-2781. [CrossRef] [PubMed]

68. Chubanov, V.; Schafer, S.; Ferioli, S.; Gudermann, T. Natural and Synthetic Modulators of the TRPM7 Channel. Cells 2014, 3, 1089-1101. [CrossRef] [PubMed]

69. Chubanov, V.; Schnitzler, M.M.; Meißner, M.; Schäfer, S.; Abstiens, K.; Hofmann, T.; Gudermann, T. Natural and synthetic modulators of SK (Kca2) potassium channels inhibit magnesium-dependent activity of the kinase-coupled cation channel TRPM7. Br. J. Pharmacol. 2012, 166, 1357-1376. [CrossRef] [PubMed]

70. Prakriya, M.; Lewis, R.S. Separation and characterization of currents through store-operated crac channels and $\mathrm{Mg}^{2+}$-Inhibited Cation (MIC) channels. J. Gen. Physiol. 2002, 119, 487-507. [CrossRef] [PubMed]

71. Li, M.; Jiang, J.; Yue, L. Functional characterization homo- and heteromeric channel kinases TRPM6 and TRPM7. J. Gen. Physiol. 2006, 127, 525-537. [CrossRef] [PubMed]

72. Kozak, J.A.; Kerschbaum, H.H; Cahalan, M.D. Distinct properties of crac and mic channels in RBL cells. J. Gen. Physiol. 2002, 120, 221-235. [CrossRef] [PubMed]

73. Chen, X.; Numata, T.; Li, M.; Mori, Y.; Orser, B.A.; Jackson, M.F.; Xiong, Z.G.; MacDonald, J.F. The modulation of TRPM7 currents by nafamostat mesilate depends directly upon extracellular concentrations of divalent cations. Mol. Brain 2010, 3, 38. [CrossRef] [PubMed]

74. Parnas, M.; Peters, M.; Dadon, D.; Lev, S.; Vertkin, I.; Slutsky, I.; Minke, B. Carvacrol is a novel inhibitor of Drosophila TRPL and mammalian TRPM7 channels. Cell Calcium 2009, 45, 300-309. [CrossRef] [PubMed]

75. Chen, H.C.; Xie, J.; Zhang, Z.; Su, L.T.; Yue, L.; Runnels, L.W. Blockade of TRPM7 channel activity and cell death by inhibitors of 5-lipoxygenase. PLoS ONE 2010, 5, e11161. [CrossRef] [PubMed]

76. Qin, X.; Yue, Z.; Sun, B.; Yang, W.; Xie, J.; Ni, E.; Feng, Y.; Mahmood, R.; Zhang, Y.; Yue, L. Sphingosine and FTY720 are potent inhibitors of the transient receptor potential melastatin 7 (TRPM7) channels. Br. J. Pharmacol. 2013, 168, 1294-1312. [CrossRef] [PubMed] 
77. Hofmann, T.; Schäfer, S.; Linseisen, M.; Sytik, L.; Gudermann, T.; Chubanov, V. Activation of TRPM7 channels by small molecules under physiological conditions. Pflugers Arch. 2014, 466, 2177-2189. [CrossRef] [PubMed]

78. Schäfer, S.; Ferioli, S.; Hofmann, T.; Sierler, S.; Gudermann, T.; Chubanov, V. Mibefradil represents a new class of benzimidazole TRPM7 channel agonists. Pflugers Arch. 2016, 468, 623-634. [CrossRef] [PubMed]

(C) 2017 by the author. Licensee MDPI, Basel, Switzerland. This article is an open access article distributed under the terms and conditions of the Creative Commons Attribution (CC BY) license (http:/ / creativecommons.org/licenses/by/4.0/). 